\title{
Penelitian
}

\section{Pencitraan Ultrasonografi Organ Reproduksi Domba Jantan Ekor Tipis Indonesia}

\author{
(Ultrasonographic Imaging of The Indonesian Male Thin Tailed Sheep's Reproduction Organ) \\ Mokhamad Fakhrul Ulum ${ }^{1,3^{*}}$, Devi Paramitha², Zultinur Muttaqin², Nur Fitri Utami', Nindya Dwi Utami', \\ Gunanti', Deni Noviana' \\ 1Departemen Klinik, Reproduksi dan Patologi, Fakultas Kedokteran Hewan, Institut Pertanian Bogor, \\ ${ }^{2}$ Sekolah Pascasarjana (SPs) Institut Pertanian Bogor, Indonesia \\ ${ }^{3}$ Departemen Ilmu Penyakit Hewan dan Kesehatan Masyarakat Veteriner, Fakultas Kedokteran Hewan, Institut \\ Pertanian Bogor, Jl. Agatis Kampus IPB Dramaga Bogor, 16680 Indonesia \\ *Penulis untuk korespondensi: fakhrul_ulum@yahoo.com \\ Diterima 18 Desember 2012, Disetujui 22 April 2013
}

\begin{abstract}
ABSTRAK
Penelitian ini bertujuan untuk mengetahui pencitraan struktur jaringan penyusun organ reproduksi jantan pada domba ekor tipis (DET) melalui pencitraan B-Mode ultrasonografi. Penelitian ini menggunakan 3 ekor DET jantan dengan berat 14-16 kg berumur 10-12 bulan. Pencitraan ultrasonografi dilakukan secara langsung pada domba tanpa menggunakan anestesi atau sedasi. Transduser linear berfrekuensi 7,5-15 MHz digunakan untuk memeriksa organ reproduksi jantan meliputi preputium, penis, epididimis, dan testis. Pemeriksaan dilakukan secara melintang dan memanjang dalam proses pemindaian. Hasil yang didapat adalah struktur jaringan penyusun organ reproduksi jantan dapat terlihat jelas dengan ekogenitas yang bervariasi. Bagian organ juga dapat dibedakan melalui pencitraan ultrasonografi sesuai dengan bentuk struktur jaringan penyusun organ yang diamati.

Kata kunci: B-mode ultrasonografi, organ reproduksi jantan, domba ekor tipis
\end{abstract}

\begin{abstract}
The present study has been carried out to evaluate the Indonesian male thin tailed sheep on B-mode ultrasound imaging. For this purpose, 3 Indonesian male thin tailed sheep with 14-16 kg in body weight and 10-12 month old were used in this study. The sheep handling and restrain were done manually without sedation or anesthesia. Linear transducers with 7.5-15 MHz were used to evaluation of architecture tissue reproductive organ including prepuce, penile, epididymis, and testicles in long axis and short axis view. The results showed that architecture tissue male reproduction organ were clearly appearance during ultrasound evaluation with echogenecity variation based on tissue. Each architecture appearance of organ can be differentiated using ultrasound imaging.
\end{abstract}

Keywords: B-mode ultrasonography, male reproductive organ, Indonesian thin tailed sheep

\section{PENDAHULUAN}

Domba merupakan hewan ternak penghasil daging, susu, kulit dan produk lainnya untuk kepentingan hidup manusia. Sebagai hewan ternak, domba banyak ditemukan hampir di seluruh wilayah Indonesia. Domba di Indonesia terdiri dari dua bangsa yaitu domba Ekor Tipis (DET) dan domba Ekor Gemuk (DEG) (Bradford \& Inounu, 1996). Sutama (1992) melaporkan bahwa pengembangan
DEG banyak dilakukan di wilayah Indonesia bagian timur dengan kondisi agroekosistem yang kering. Sedangkan DET banyak ditemukan di Indonesia bagian barat dengan iklim yang basah dan memiliki ketersediaan hijauan yang cukup banyak untuk kelangsungan hidup. Penyebaran DET banyak terdapat di wilayah Jawa Barat dan Jawa Tengah (Suparyantoet al., 1999).

Budidaya dan pengembangan populasi domba sangat erat kaitannya dengan sistem reproduksi. 
Domba jantan idealnya diperiksa status kesehatan reproduksinya pada usia 2 bulan sebelum memasuki masa dewasa kelamin (Viñoles-Gil et al., 2010). Kondisi kesehatan organ reproduksi secara klinis umumnya dilakukan dengan palpasi maupun inspeksi pada penis, testis dan skrotum yang diikuti dengan pemeriksaan makroskopis dan mikroskopis pada semen (Boundy, 1992), akan tetapi kondisi kesehatan pada struktur jaringan penyusun organ tidak dapat diketahui dengan baik melalui tehnik ini. Teknik diagnostik yang cukup handal dan sensitif pada jaringan lunak adalah melalui pencitraan ultrasonografi (Noviana et al., 2012). Pertamakali ultrasonografi digunakan pada ruminansia kecil sejak tahun 1983 untuk pemeriksaan kebuntingan pada domba (Tainturier et al., 1983a) dan kambing (Tainturier et al., 1983b), menghitung jumlah fetus domba (Buckrell, 1988; Garcia et al., 1993), kambing (Martínez et al., 1998; Gonalez et al., 2004; Abdelghafar et al., 2007), rusa (Revol \& Wilson, 1991), dan rusa kutub (Vahtiala et al., 2004) serta menentukan usia kebuntingan pada kambing (Amer, 2008). Data hasil pencitraan ultrasonografi pada struktur jaringan penyusun organ reproduksi jantan DET Indonesia hingga saat ini sangat sulit didapatkan karena belum pernah dilaporkan. Dengan demikian penelitian ini dimaksudkan untuk mengetahui gambaran anatomi struktur jaringan penyusun organ reproduksi jantan DET melalui pencitraan Brightness-mode (B-mode) ultrasonografi.

\section{BAHAN DAN METODE}

Penelitian ini menggunakan domba ekor tipis sebanyak 3 ekor, berjenis kelamin jantan, berumur 1012 bulan dengan berat badan 14-16 kg. Pencitraan dilakukan menggunakan portable ultrasonografi (SonoDop ${ }^{\circledR}$ S6-X, PT Karindo Alkesteron, Indonesia) dengan transduser linear (frekuensi 7,5-15
$\mathrm{MHz}$ ). Hewan dipegang secara langsung dan dibaringkan pada posisi dimiringkan ke samping kanan ataupun kiri (lateral recumbence) yang nyaman tanpa menggunakan sedasi atau pembiusan. Rambut pada daerah pemeriksaan dilakukan pencukuran hingga bersih dan digunakan gel ultrasound untuk memperoleh gambar yang baik (Gambar 1). Pemeriksaan dilakukan pada potongan memanjang dan melintang (Gambar 2) mulai dari preputium, penis, epididimis dan testikel (Gonzalez-Bulnes et al., 2010). Interpretasi dilakukan secara real time dan sonogram yang diperoleh disimpan dalam gambar digital.

\section{HASIL}

\section{Preputium dan Glans Penis (Bagian Prosesus Uretralis)}

Preputium merupakan kulit pembungkus yang berfungsi sebagai pelindung penis. Pencitraan ultrasonografi preputium terlihat lumen preputium berwarna hitam (hipoekhoik) dengan batas kulit yang berwarna putih (hiperekhoik). Kulit preputium tampak lebih hiperekhoik karena jaringan penyusun kulit lebih banyak memantulkan suara dari pada jaringan spongiosa. Glans penis bagian prosesus uretralis terlihat hiperekhoik pada daerah lumen yang hipoekhoik (Gambar 3). Peritoneum tampak sebagai garis hiperekhoik dengan garis anekhoik yang diikuti dengan tampilan bayangan akustik (acoustics shadowing) pada rongga perut.

\section{Penis}

Penis merupakan organ kopulasi pada hewan jantan yang terdiri dari pangkal, badan dan glans penis yang disertai dengan prosesus uretralis. Pencitraan ultrasonografi glans penis terlihat sebagai
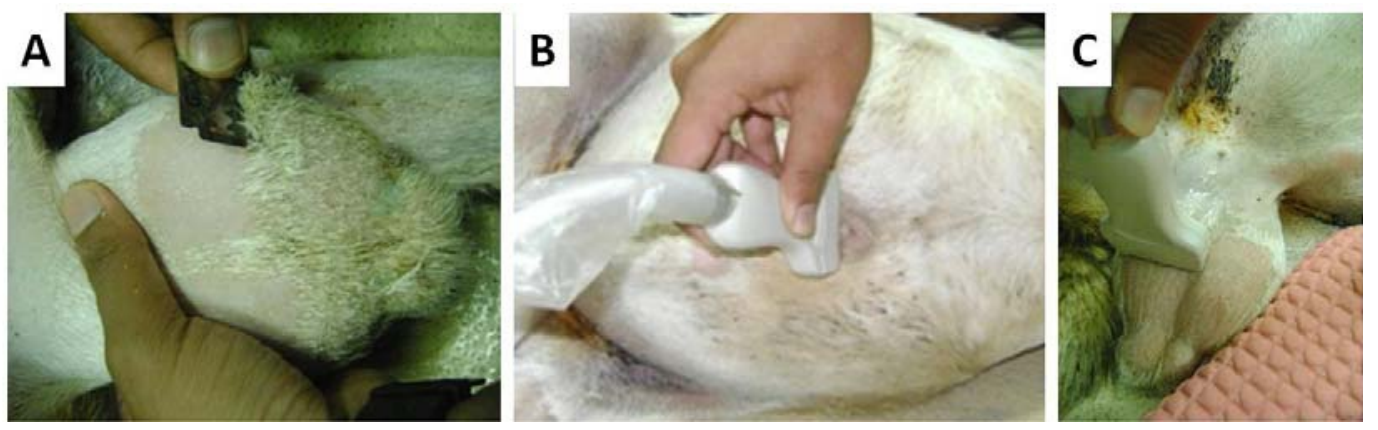

Gambar 1 Pemeriksaan ultrasonografi organ reproduksi domba jantan ekor tipis (DET) Indonesia. A. Pencukuran rambut pada daerah orientasi, B. Pemeriksaan ultrasonografi pada preputium, C. Pemeriksaan ultrasonografi pada testis. 

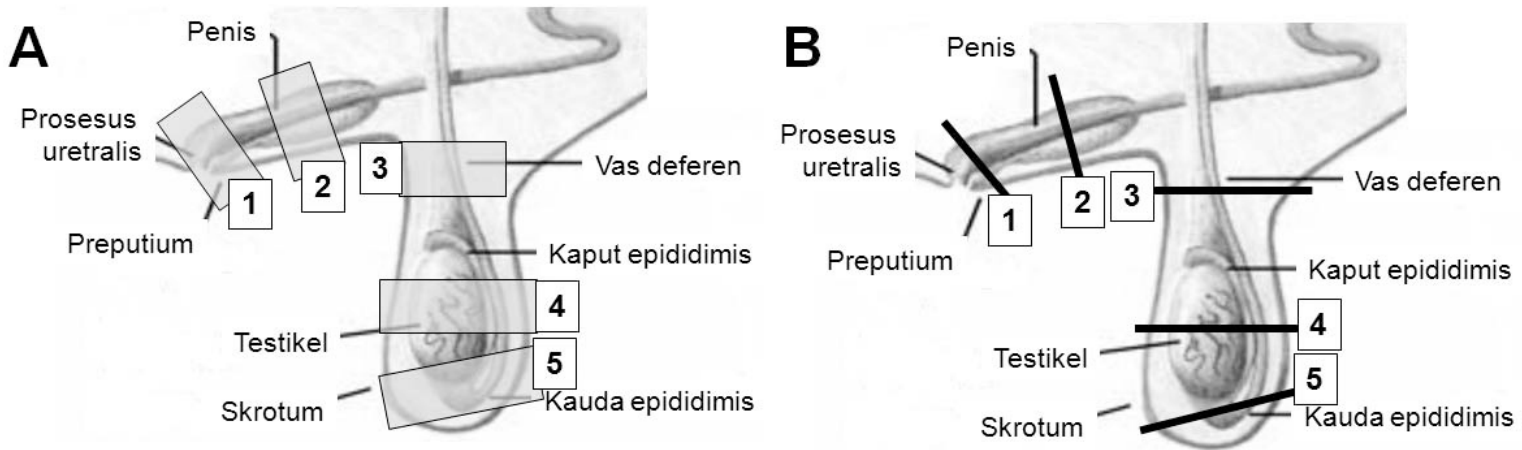

Gambar 2 Daerah pencitraan ultrasonografi pada organ reproduksi domba jantan ekor tipis (DET) Indonesia (modifikasi dari Abebe, 2008). A. Pencitraan dengan potongan memanjang, B. Pencitraan dengan potongan melintang, 1=preputium, 2=badan penis, 3=kaput epididimis, 4=badan testis, 5=kauda epididimis.
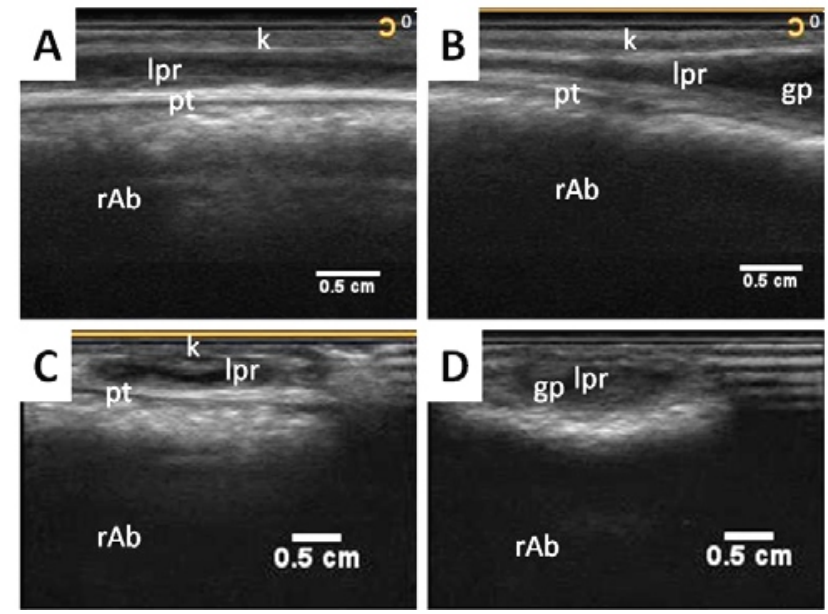

Gambar 3 Sonogram preputium dan awal glans penis. $A, C$. preputium; B,D. glans penis bagian prosesus uretralis; $A, B$. potongan memanjang;

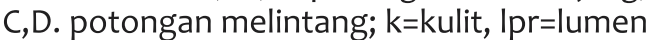
preputium, $\mathrm{pt}=$ peritoneum, $\mathrm{gp}=\mathrm{glans}$ penis, $r A b=$ rongga perut.

struktur hipoekhoik dengan bagian tengahnya hipo- dan an-ekhoik. Variasi tampilan ekhogenitas pada glans penis karena bentuk glans penis yang dilengkapi dengan prosesus uretralis yang melipat sehingga batas antara prosesus dengan glans penis terlihat anekhoik. Beberapa bagian dari glans penis tampak variasi ekhogenitas karena pada bagian organ ini tersusun atas jaringan spongiosa yang banyak terdapat pembuluh darah (Gambar 4).

Penis terletak dalam selubung kulit abdomen dan berujung pada preputium sebagai gerbang pintu penghubung dengan dunia luar. Pencitraan ultrasonografi dari badan penis terlihat berupa struktur hipoekhoik yang dibatasi oleh area anekhoik sebagai rongga batas antara badan penis dengan kulit pembungkus. Uretra terlihat sebagai struktur anekhoik di tengah badan penis (Gambar 5).
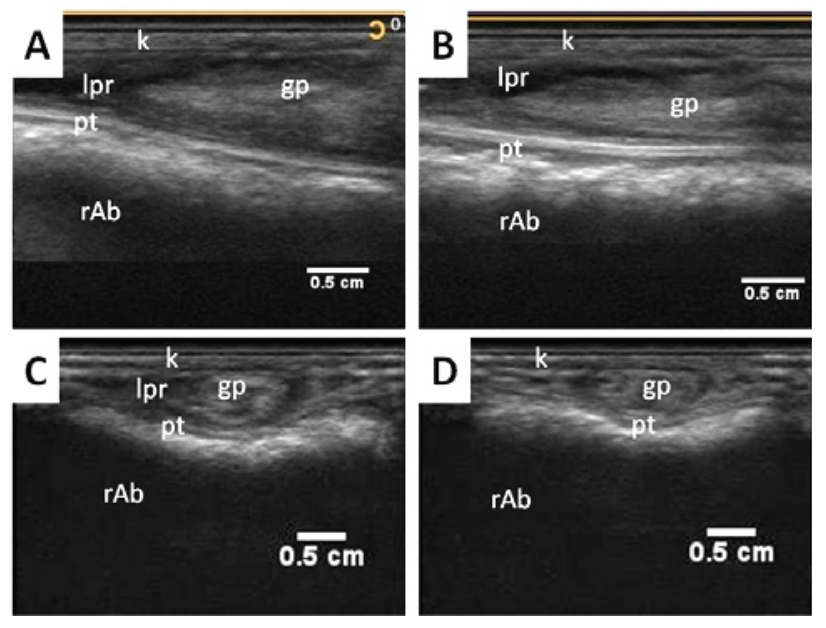

Gambar 4 Sonogram glans penis; A,B. potongan memanjang; C,D. potongan melintang. $k=k u l i t$, Ipr=lumen preputium, $\mathrm{pt=peritoneum,} \mathrm{gp=}$ glans penis, $r A b=$ rongga perut.

\section{Epididimis}

Epididimis merupakan saluran tunggal memanjang berliku pada sisi medial testis. Ujung dari duktus epididimis adalah prosesus uretralis yang terletak pada ujung glans penis. Pencitraan ultrasonografi kaput epididimis terlihat sebagai kombinasi struktur hipoekhoik dengan anekhoik. Struktur anekhoik merupakan duktus epididimis dan struktur jaringan saluran tampak hipoekhoik. Ukuran duktus pada kauda epididimis terlihat lebih besar jika dibandingkan dengan pada bagian kaput epididimis, sehingga tampilan anekhoik lebih dominan pada bagian ini (Gambar 6). Kulit bagian skrotum terlihat sebagai garis hipo- hingga hiperekhoik. 

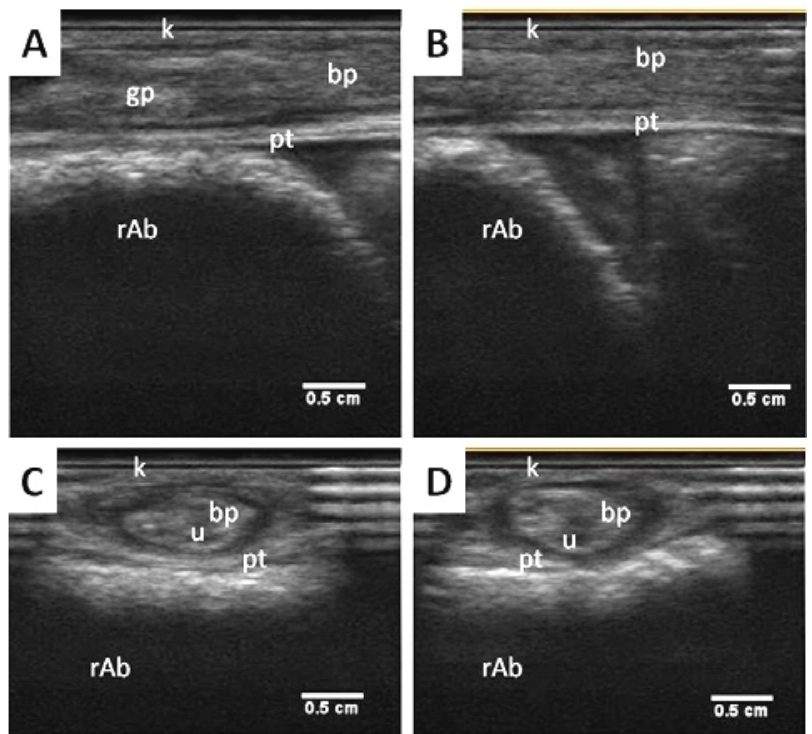

Gambar 5 Sonogram badan penis; A,C. awal badan penis; B,D. badan penis; A,B. potongan melintang; C,D. potongan memanjang. k=kulit, $\mathrm{pt}=$ peritoneum, gp=glans penis, $\mathrm{bp}=$ badan penis, $u=u r e t r a, r A b=$ rongga perut.
Testis

Testis merupakan organ utama yang menghasilkan sel sperma untuk proses reproduksi. Testis dilindungi oleh skrotum yang terdiri atas dua kantong (lobus) kanan dan kiri. Badan testis secara ultrasonogafi tampak sebagai struktur hipoekhoik yang difus. Bagian tepi tampak batas yang terlihat hiperekhoik, batas ini merupakan jaringan ikat penyusun kantung skrotum (Gambar 7). Tunika albuginea merupakan jaringan ikat dan serabut otot polos yang berhubungan langsung dengan jaringan parenkim testis. Tunika ini terlihat sebagai struktur hiperekhoik di bagian tengah organ sebagai jaringan ikat yang berada diantara lobuli penghasil spermatozoa. Pembuluh darah di dalam testis tampak sebagai struktur anekhoik.
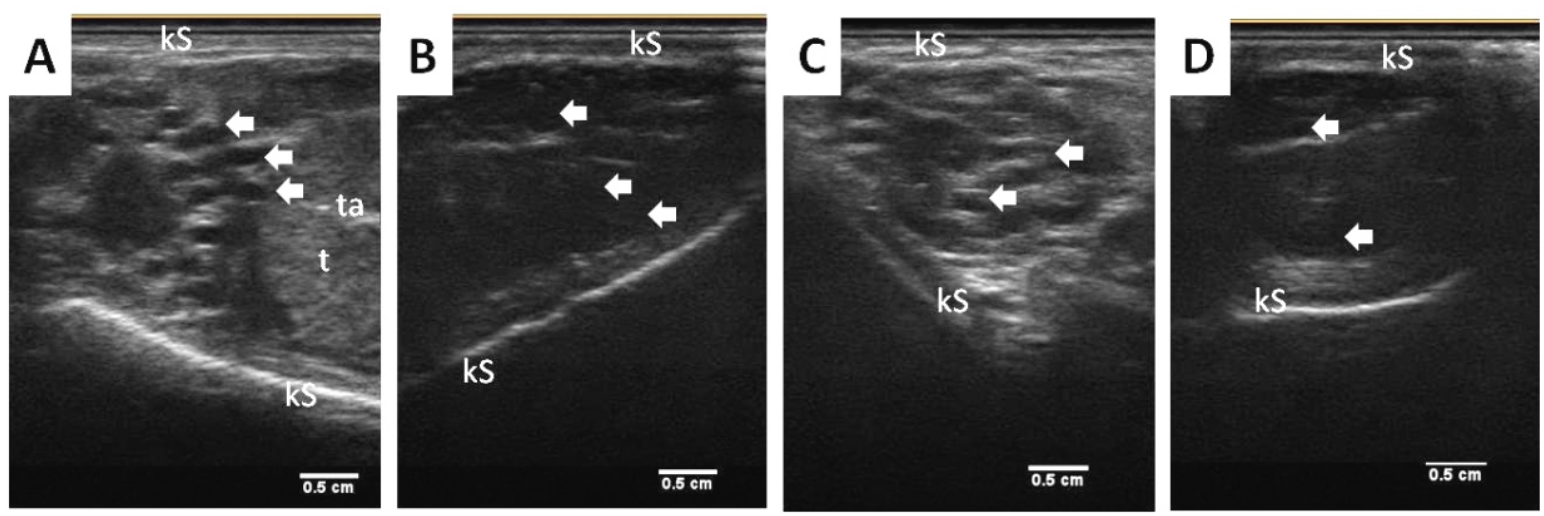

Gambar 6 Sonogram epididimis. A,B potongan memanjang; C,D. potongan melintang; A,C. kaput epididimis; $B, D$. kauda epididimis. $k S=$ skrotum, $t=$ testis, ta=tunika albugenia, panah putih=duktus epididimis.
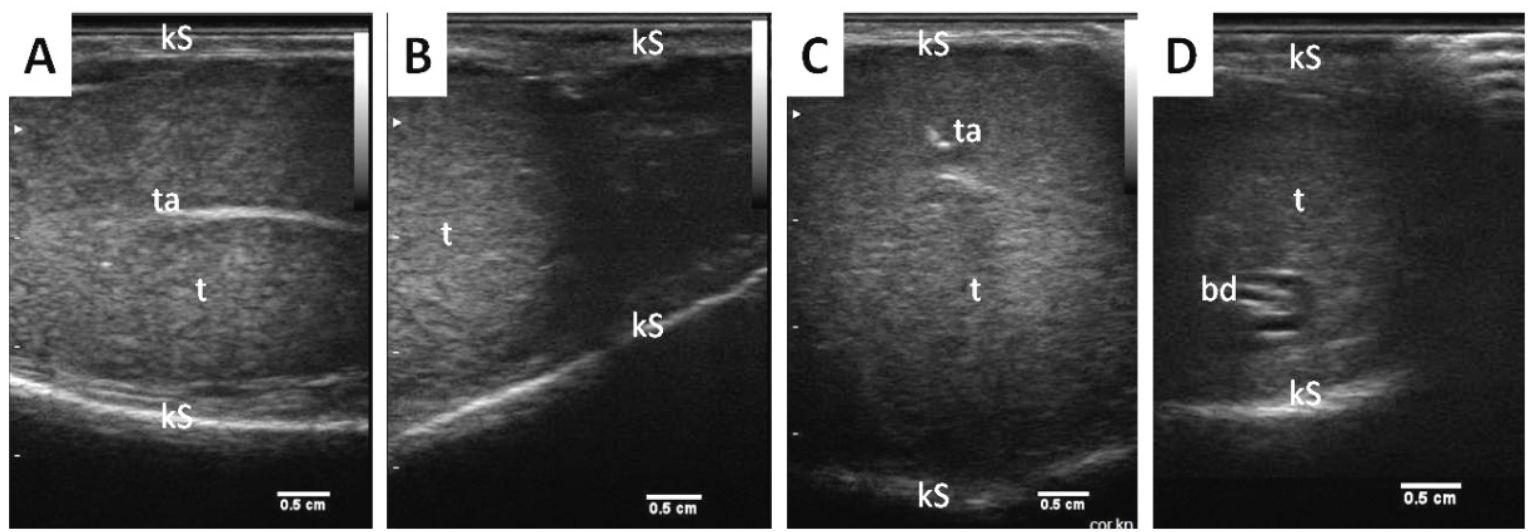

Gambar 7 Sonogram testikel. A,B. potongan memanjang; C,D. potongan melintang. $\mathrm{KS}=$ skrotum, $\mathrm{t}=$ testis, ta=tunika albugenia, bd=pembuluh darah testis. 


\section{PEMBAHASAN}

Evaluasi kesehatan organ reproduksi jantan dapat dilakukan melalui pemeriksaan laboratorium pada semen untuk mengetahui morfologi dan motilitas sperma (Kheradmand et al., 2006). Metode umum lainnya pada tindakan evaluasi pemilihan pejantan terbaik (breeding soundness evaluation) biasanya dilakukan pemeriksaan pada lingkar testis, kualitas semen, kemampuan fisik, dan kesehatan seluruhnya (Godfrey \& Dodson, 2005). Evaluasi melalui teknik ini memiliki keterbatasan yaitu tidak dapat mengetahui kondisi kesehatan organ reproduksi pada struktur jaringan penyusun organ.

Evaluasi kondisi kesehatan struktur jaringan penyusun organ sistem reproduksi dapat dilakukan dengan pendekatan metode B-mode ultrasonografi secara trankutaneus. Ultrasonografi telah digunakan untuk memonitor status kesehatan dan produktifitas hewan ternak lebih dari seperempat abad (Lamb, 2001) termasuk hubungannya dengan kadar hormon testosteron (Wu et al., 2010). Tindakan pemeriksaan ultrasonografi untuk mengetahui kondisi morfologi organ reproduksi telah digunakan pada pemeriksaan testis babi rusa (Cartee et al., 1986) dan sapi (Pechman \& Eilts, 1987; Eilts \& Pechman, 1988). Menurut Griffin \& Ginther (1992), pencitraan ultrasonografi organ reproduksi sangat penting dilakukan untuk mengetahui morfologi normal, degenerasi maupun kejadian penyakit.

Penggunaan ultrasonografi termasuk dalam kategori non-invasif atau tidak menimbulkan rasa sakit atau perdarahan pada hewan (Glasbey et al., 1996). Prinsip kerja ultrasonografi adalah memanfaatkan gelombang suara berfrekuensi sangat tinggi dari tranduser sekaligus menghasilkan citra struktur hasil pantulan (gema) yang ditangkap kembali untuk ditampilkan menjadi suatu gambar (Noviana et al., 2012). Melalui prinsip kerja ultrasonografi ini, pemeriksaan organ tidak merusak jaringan. Gelombang suara pada ultrasonografi tersebut tidak mempengaruhi kondisi kesehatan hewan dan secara ekonomis membutuhkan biaya aplikasi yang relatif murah (Conington et al., 1995; Larsgard \& Kolstad, 2003). Sehingga Cemal et al. (2007) menyarankan untuk menggunakan teknik ultrasonografi pada peternakan budidaya (breeding farm) karena hasil monitoring kesehatan organ reproduksi dapat dengan cepat dilakukan dan cepat diperoleh hasilnya secara real-time.

Pencitraan organ secara ultrasonografi dengan komposisi cairan akan terlihat sebagai warna hitam (anekhoik), komposisi jaringan lunak berwarna abu-abu (hipoekhoik), dan komposisi udara atau jaringan keras berwarna putih (hiperekhoik) (Noviana et al., 2012). Pencitraan ultrasonografi organ reproduksi DET jantan secara umum dapat dievaluasi dan dianalisa melalui tehnik B-mode ultrasonografi dengan mudah tanpa penggunaan sedasi maupun anestesi. Perubahan pencitraan ultrasonografi pada organ yang diperiksa dapat dijadikan pedoman awal adanya abnormalitas atau kelainan organ reproduksi. Konfirmasi lebih lanjut terhadap kualitas sperma dapat dilakukan secara laboratorium untuk menegakkan diagnosa jika terjadi perubahan ekhogenitas pada jaringan maupun organ.

Data pada penelitian ini dapat disimpulkan bahwa metode pencitraan B-mode ultrasonografi dapat digunakan sebagai sarana penunjang diagnosa sekaligus untuk melakukan evaluasi pada struktur jaringan dalam menentukan status kesehatan organ reproduksi.

"Penulis menyatakan tidak ada konflik kepentingan dengan pihak-pihak yang terkait dalam penelitian ini"

\section{DAFTAR PUSTAKA}

Abebe G. 2008. Reproduction in Sheep and Goats. In: Yami A, Merkel RC (eds). Sheep and Goat Production Handbook for Ethiopia. Ethiopia Sheep and Goat Productivity Improvement Program (ESGPIP). Ethiopia. P59-79.

Abdelghafar RM, Bakhiet AO, Ahmed BH. 2007. BMode Real-Time Ultrasonography for Pregnancy Diagnosis and Fetal Number in Saanen Goats. Journal of Animal and Veterinary Advances 6(5): 702-705.

Amer HA. 2008. Determination of first pregnancy and foetal measurements in Egyptian Baladi goats (Capra hircus). Veterinaria Italiana 44(2): 429-437.

Boundy T. 1992. Routine ram examination. In Practice 14: 219-228.

Bradford GE, Inounu I. 1996. Prolific breed in Indonesia. In: Fahmy MH (ed). Prolific Sheep. CAB International. p137-145.

Buckrell BC. 1998. Application of ultrasonography in reproduction in sheep and goats. Theriogenology 29(1): 71-84.

Cartee RE, Powe TA, Gray BW, Hudson RS, Kublers DL. 1986. Ultrasonographic evaluation of normal boar testicles. American Journal of Veterinary Research 47: 25-43. 
Cemal I, Karaca O, Altin T, Gokdal O, Yilmaz M, Yilmaz O. 2007. Ultrasound measurement of eye muscle properties and backfat thickness in $\mathrm{Ki}$ vircik Lambs. Journal of Biological Sciences 7(1): 89-94.

Conington J, Bishop SC, Waterhouse A, Simm G. 1995. A genetic analysis of early growth and ultrasonic measurements in hill sheep. Journal of Animal Science 61: 85-93.

Eilts BE, Pechman RD. 1988. B-mode ultrasound observations of bull testes during breeding soundness examinations. Theriogenology 30: 1169.

Garcia A, Neary MK, Kelly GR, Pierson RA. 1993. ACcuracy of ultrasonography in early pregnancy diagnosis in the ewe. Theriogenology 39: 847-861.

Glasbey CA, Abdalla I, Simm G. 1996. Towards automatic interpretation of sheep ultrasound scans. Journal of Animal Science 62: 309-315.

Godfrey RW, Dodson RE. 2005. Breeding soundness evaluations of senepol bulls in the US virgin islands. Theriogenology 63(3): 831-40.

Gonalez FC, Batista M, Rodriguez N, Alamo D, SuIon J, Beckers JF, Gracia A. 2004. A comparison of diagnosis of pregnancy in the goat via transrectal ultrasound scanning, progesterone and pregnancy-associated glycoprotein assays. Theriogenology 62: 1108-1115.

Gonzalez-Bulnes A, Pallares P, Vazquez MI. 2010. UItrasonography in Small Ruminant Reproduction. Reproduction in Domestic Animal 45(2): 9-20.

Griffin PG, Ginther OJ. 1992. Research applications of ultrasonic imaging in reproductive biology. Journal of Animal Science 70: 953-972.

Kheradmand A, Babaei H, Batavani RA. 2006. Effect of improved diet on semen quality and scrotal circumference in the ram. Veterinarski arhiv 76: 333-341.

Lamb GC. 2001. Reproductive Real-Time Ultrasound Technology: An Application for Improving Calf Crop in Cattle Operations. In: Fields MJ (ed). Factors Affecting Calf Crop: Biotech $n$ nology of Reproduction. CRC Press. Boca Raton, FL. p231-153.

Larsgard AG, Kolstad K. 2003. Selection for ultrasonic muscle depth: direct and correlated response in Norwegian experimental sheep flock. Small Ruminant Research 48: 23-29.

Martínez MF, Bosch P, Bosch RA. 1998. Determination of early pregnancy and embryonic growth in goats by transrectal ultrasound scanning. Theriogenology 49: 1555-1565.
Noviana D, Aliambar SH, Ulum MF, Siswandi R. 2012. Diagnosis Ultrasonografi pada Hewan Kecil. IPB Press. Bogor. p1-12.

Pechman RD, Eilts BE. 1987. B-mode ultrasonography of the bull testicle. Theriogenology 27: 431441.

Revol B, Wilson PR. 1991. Foetal ageing in farmed red deer using real-time ultrasonography. Animal Reproduction Science 25: 241-253.

Suparyanto A, Purwadaria T, Subandriyo. 1999. The estimation of genetic distance and discriminant variables on breed of Indonesian sheep by morphological analysis. Jurnal Ilmu Ternak dan Veteriner 4(2): 80-87.

Sutama IK. 1992. Domba Ekor Gemuk di Indonesia: Potensi dan permasalahannya. Prosiding Sarasehan Usaha Ternak Domba dan Kambing Menyongsong Era PJPT II. Ikatan Sarjana IImu-IImu Peternakan Cabang Bogor dan Himpunan Peternak Domba dan Kambing Indonesia Cabang Bogor. p78-84.

Tainturier D, Lijour L, Chaari M, Sardjana KW, Denis B. 1983a. Diagnostic de la gestation chez la brebis par échotomographie. Recueil de Médicine Vétérinaire 134: 523-526.

Tainturier D, Lijour L, Chaari M, Sardjana KW, Lenet JL. 1983b. Diagnostic de la gestation chez la chévre par échotomographie. Recueil de Médicine Vétérinaire 134: 597-599.

Vahtiala S, Sakkinen H, Dahl E, Eloranta E, Beckers JF, Ropstad E. 2004. Ultrasonography in early pregnancy diagnosis and measurements of fetal size in reindeer (Rangifer tarandus tarandus). Theriogenology 61: 785-795.

Viñoles-Gil C, Gonzalez-Bulnes A, Martin GB, Sales F, Sale S. 2010. Sheep and Goats. In: DesCôteaux L, Colloton J, Gnemmi G (eds). Practical Atlas of Ruminant and Camelid Reproductive Ultrasonography. Wiley-Blackwell publishing. USA. p181-223.

Wu H-P, Hao Y-J, Li X, Zhao Q-Z, Chen D-Q, Kuang X-A, Kou Z-B, Feng K-K, Gong W-M, Wang D. 2010. BMode ultrasonographic evaluation of the testis in relation to serum testosterone concentration in male Yangtze finless porpoise (Neophocaena phocaenoides asiaeorientalis) during the breeding season. Theriogenology 73: 383-391. 